\section{Brandeis $\left.\right|_{\text {wrewer }}$}

brandeis.edu/j-caste
CASTE: A Global Journal on Social Exclusion

Vol. 1, No. 1, pp. 217-228

February 2020

ISSN 2639-4928

DOI: 10.26812/caste.v1i1.54

\title{
Dalit or Brahmanical Patriarchy? Rethinking Indian Feminism
}

\author{
Sunaina Arya' \\ (Bluestone Rising Scholar Honorable Mention 2019)
}

\begin{abstract}
This paper argues that the conceptualisation of notions like 'dalit' or 'intracaste' or 'multiple' patriarchies results from a misunderstanding of the concept brahmanical patriarchy. The category 'dalit patriarchy' is gaining popularity in academic and political discourse of contemporary India. It is introduced by Gopal Guru in his seminal essay 'Dalit Women Talk Differently' only to challenge patriarchal practices within 'lower' caste groups. But mainstream feminists of India attempted to propagate and proliferate this vague concept. They argue that dalit men, as a part of their exploitation by 'upper' caste, also face taunts regarding their masculinity which results in their aggressive behaviour towards dalit women; which has been termed as 'dalit patriarchy.' The paper argues that conceptualisation of such notions yields no advancement in our endeavours toward a gender-just society, rather it is misleading. Evaluating articulations in mainstream Indian feminism, we need to think through: What effect does this have on our feminist struggle? What is at stake? What possibly can be a resolution? Thus, by exposing flaws about 'dalit patriarchy'-including a detailed discussion on the empirical, theoretical, and logical shortcomings - this paper seeks to initiate a theoretical rethinking of feminist as well as dalit scholarship, with employment of analytical, hermeneutical, and critical methods.
\end{abstract}

\section{Keywords}

Dalit, feminism, brahmanical, patriarchy, Ambedkar, gender, caste, race, class, philosophy, women

\section{Introduction}

Contemporary writings in Indian feminism pose some difficulties towards theorising gender. This paper argues that a conception of notions like 'dalit patriarchy' or 'intracaste' or 'multiple' patriarchies, is a consequence of a perfunctory understanding of the concept brahmanical patriarchy. Mulling around

\footnotetext{
'Senior Research Fellow, Jawaharlal Nehru University, New Delhi, India E-mail: sunainaarya9@gmail.com
}

(C) 2020 Sunaina Arya. This is an open access article distributed under the terms of the Creative Commons Attribution License, which permits unrestricted use, distribution, and reproduction in any medium, provided the original author(s) and source are credited 
both the ideas offers a conclusion that mainstream Indian feminists' approach toward gender justice is incomprehensive and uncommitted. Thus, it proposes to rethink Indian feminist discourse with specific focus on its socio-cultural difference from rest of the world. This implies that theorising from a dalit feminist standpoint is the only way to consummate feminist philosophy, specifically for the Indian subcontinent, and in general. Let us see, how.

While thinking through various aspects of dalit reality, political theorist Gopal Guru reflected upon the patriarchal control over dalit women within their caste group which he vaguely called 'dalit patriarchy' (Guru, 1995, p. 2549). He was critical of the patriarchal norms and practices prevalent within the dalit community, while having no intentions of creating a major hurdle for dalit feminists today. In recent times, mainstream Indian feminists have furthered the concept and attempted to popularise it as a separate form of patriarchy free from the umbrella of brahmanical patriarchy. They suggest that dalit men, as a part of their exploitation by 'upper'1 caste, also face taunts regarding their masculinity which results in their aggressive behaviour on dalit women (Chakravarti, 2013 [2003], p. 86; Geetha, 2009, p. 108). This is discussed in detail in the first section of the paper.

The popularity of 'dalit patriarchy' is ever increasing in contemporary feminist scholarship. Lucinda Ramberg builds her perspective 'upon the feminist anti-caste scholarship of Anjali Arondekar, Charu Gupta, Gail Omvedt, Shailaja Paik, Sharmila Rege, and Anupama Rao, who have described 'untouchable' womanhood as unfolding within two patriarchies - brahmanical and dalit' (Ramberg, in Rao 2018). Kumkum Sangari titles her paper on religious diversity around 'multiple patriarchies' without any discussion or engagement with its meaning (1995 p. 3295). Not only mainstream Indian and western scholars but also dalit feminists are left unaffected by this category. Shailaja S. Paik recollects Ambedkar's feminist movement: by 'giving up castespecific, stigmatised dressing styles and heavy jewellery, dalit women asserted against both Brahmanical (caste and gender codes) as well as intracaste patriarchies' (Paik, 2016; Tilak, 2018). Reviewing Dutt's memoir, Coming Out as Dalit, Dhanaraj mentions 'inter- and intra-caste patriarchies' (Dhanaraj, 2019; Dutt, 2019). This high granting of such terms to be true is counterproductive for our feminist emancipatory goals. What we require is to think carefully upon such interventions for a comprehensive picture of the mode of patriarchy at play.

We find two presumed phenomena related with the conceptualisation of dalit patriarchy. One, it is distinct from brahmanical patriarchy, and secondly, there exist multiple patriarchies. Chakravarti writes, 'as Ambedkar had pointed to caste as a system of graded inequalities, we should note that patriarchies in the subcontinent were contained within a larger system which was graded according to caste' (Chakravarti, 2013[2003], p. 83). Let us ponder upon the origin and definition of dalit patriarchy and observe whether it is actually 'graded according to caste'.

\section{Dalit Patriarchy: What is it?}

\section{First Formulation}

Gopal Guru, in his seminal essay 'Dalit Women Talk Differently,' formulates dalit patriarchy in the following context: 
Besides th[e] external factors, there are certain internal factors that have prompted dalit women to organise separately vis-a-vis dalit men. In the post-Ambedkar period, dalit leaders have always subordinated, and at times suppressed, an independent political expression of dalit women.... Dalit women rightly question why they are not considered for the top positions in dalit literary conferences and institutions. This dissent brings three things to the fore: (1) It is not only caste and class identity but also one's gender positioning that decides the validity of an event; (2) Dalit men are reproducing the same mechanisms against their women which their high caste adversaries had used to dominate them; (3) The experience of dalit women shows that local resistance within dalits is important. The whole situation compels us to defend the claim that dalit women talk differently (Guru, 1995, p. 2549).

In conceptualisation of dalit patriarchy, three things which Guru brings forth, in other words, are-gender is as important as caste and class in the struggle towards a just society; patriarchy is rooted in dalit men as casteism is in the 'high' caste people; it is experientially evident that 'local' resistance within dalits is necessary. It is clear that he conceived of this category against the patriarchal dominance which dalit women face, encouraging feminist resistance from within. But none of his implications justify that dalit men's patriarchy is more oppressive or unique from that of savarna men. Although his claim about dalit women talking differently is crucial, calling patriarchy as 'dalit patriarchy' does not help us towards our goal of an egalitarian society. Guru's 'internal' and 'external' markers are explicated in the reference of the next formulation.

\section{Second Formulation}

A well-known feminist historian Uma Chakravarti attempts to pluralise patriarchy by employing the terms 'graded patriarchies' and 'dalit patriarchy,' arguing that 'dalit women experience patriarchy in a unique way.' Citing a dalit poet in support of her claim, Chakravarti writes:

It is not as if patriarchies do not exist among the dalit castes, or that dalit women do not have to struggle against the patriarchies within their own communities. In the words of Swaroopa Rani,

\section{When has my life been truly mine? \\ In the home male arrogance \\ Sets my cheek stinging, \\ While in the street caste arrogance \\ Splits the other cheek open.}

Whatever might have been the differences between dalit women's experience of patriarchy and that of upper caste women, the process of Sanskritisation or 'jatikarana' - intensified castification-led to upper caste norms and upper caste patriarchal practices percolation into the lower caste ranks too.

(Chakravarti, 2013 [2003], pp. 87-88)

As it is established through survey reports and abundant literary and scholarly works (Rege, 2013, pp. 20-21. See Aloysius, Mangubhai and Lee, 2006; Gogu, 2012; Jogdand, 2013; Moon, 2001; Pawar and Moon, 2014; Rege, 2000,2013 [2006], Stephen, 2011; 
Dutt, 2019), the claim above that dalit women experience patriarchy in a complex way is valid. But in the aforementioned piercing poem of Swaroopa Rani, the first line flags the struggles pertinent to dalit women's lives; the next two lines notify violence exhibiting patriarchy; and the last two lines denote brahmanical oppression.

Chakravarti argues that dalit life is not unaffected from the savarna patriarchal norms, but her use of the word 'whatever' about the difference between dalit and savarna women's experiences makes us wonder what is offered in justification of her exposition of 'dalit patriarchy.' As argued, dalit men behave in the same patriarchal manner as savarna men do, but then how is their patriarchy different from savarna? Why do we need a different term for the same phenomenon? Thus, in the absence of an explanation, this attempt renders futile for the feminist enterprise.

\section{Third Formulation}

Similar to the second, the next understanding on 'dalit patriarchy' also comes from another mainstream feminist, V. Geetha. She writes,

There have been attempts to think through caste and gender, notably the idea of 'dalit' patriarchy. There are two different arguments here: one notes that dalit men have as much a stake in masculinity as other men. A notable feature of the exploitation of dalits has been the humiliation of dalit men: in the course of the power that upper caste men exert over their labour, they also taunt them about their masculinity. They claim that dalit men can never hope to protect their women, who are considered 'easy prey' by upper caste men. Such symbolic 'emasculation' of dalit men results in their feeling beleaguered in specifically gendered ways, which results in their exerting prowess in their families. The second argument accepts the premises of the first, but notes that apart from remaining 'masculine' within, dalit men also seek to express their covert anger at the humiliation they are forced to endure by seeking to tease upper caste women.

Geetha's (2009) conception presents a slightly different picture, that the caste-based humiliation of dalit men makes them more patriarchal than other men. She refers to a study on masculine norms among dalit youth, but mistakes masculinity among them as something unique. This - including their desire of teasing upper caste women - is an empirical claim, but what do we get for a justification? In lack of evidence for a peculiarity of patriarchy as argued, such conception of dalit patriarchy is misleading.

What we have is the brahmanical oppression as the underlying reason for dalit men's behaving in a patriarchal manner; if proven, that dalit men behave 'in specifically gendered ways,' the underlying reason (as argued by both writers hitherto) is their caste-based exploitation by the savarna. Clearly, it is brahmanical patriarchy which women face. And, thinking 'through caste and gender' evidences 'brahmanical patriarchy' as unmasked by Dr. B. R. Ambedkar, not any dalit patriarchy (2003, Vol. 17, part 3, pp. 150-51).

These three are the primary understanding for conceptualising and furthering the untenable category viz. dalit patriarchy. Originally, Guru formulated it as an internal matter to be resolved locally within dalit groups. Secondly, Chakravarti pluralised patriarchy while historically locating dalit women's struggle in brahmanical Indian society. Lastly, Geetha extends dalit men's aggressive masculinity to a desire of teasing upper caste women. Let us critically evaluate these claims in the next section. 


\section{Dalit or Brahmanical Patriarchy?}

From the above formulations of dalit patriarchy, we can derive the following claims: (1) Dalit women's experience of patriarchy is unique and more intense from upper caste or savarna women; (2) Dalit men face taunts regarding their masculinity concerning the protection of the 'honour' or izzat (women's chastity) of their community; (3) Because of brahmanical exploitation at the hands of upper caste people, dalit men behave aggressively and oppress 'their' women, who are most vulnerable in the castebased social structure; (4) Dalit men's practices of patriarchy are not humble than that of the brahmin or other savarna men; (5) Outraged with brahmanical humiliation, dalit men seek to tease savarna women;(6) there exist brahmanical and dalit or intra-caste patriarchies. All of these claims are of empirical kind, where we know that only the first is objectively established. Hence, there are strong challenges against the conception of dalit patriarchy. Let us witness the common logical fallacies surrounding this spurious notion.

\section{Fallacy of Begging the Question (Pretitio Principii)}

The conclusion has been presumed to be true based on a speculated premise. In present context, it follows:

All dalit men are brahmanically exploited by the upper castes.

One of the instances of their exploitation is being mocked by symbolic 'emasculation.'

Therefore, dalit men are more patriarchal.

The second premise of the argument is unestablished due to lack of empirical evidence, and the conclusion is claimed to be true. The flawed notion of dalit patriarchy is as dubious as the idea of 'dalit egalitarianism'. That is, the dalit men are not as oppressive as upper caste men because they are humble as for understanding the pain of oppression which results from their experience of caste-based exploitation (Rege, 2013). Both of these concepts are stark presumptions, and therefore counterproductive in our feminist endeavours.

Sharmila Rege, the pioneer of Ambedkarite feminism, argues that this fallacious linkage is drawn upon the presupposition about the sexual accessibility of dalit women because of their labouring outdoors. It is but, brahminism, which in turn 'locates this as the failure of lower-caste men to control the sexuality of their women and underlines this as a justification of their impurity' (Rege, 1998). Evidently, the social manifestation of brahminism is at the heart of misconceiving 'dalit patriarchy'.

\section{Fallacy of Infinite Regress}

As per Ambedkar's scholarship on Indian history, no caste is unaffected from the patriarchal essence of brahminism. Extending this further, not only dalit men but all men face such 'emasculation' by the people from each and every caste above theirs. If we name patriarchal practices of men belonging to a particular community by the name of their caste, there would be endless number of patriarchies viz. shudra patriarchy, kayastha patriarchy, mahar patriarchy, kumhar patriarchy...and so on. 
Thus, this exercise of proliferating patriarchies only misdirects our feminist goals, leading to an infinite regress.

\section{Fallacy of Slippery Slope}

Following from invalid causal inferences, Geetha's conclusion that dalit men seek to tease upper caste women is a blunt presumption (as we have seen in the beginning of this section). The truthfulness of this argument depends upon the validity of all the previous premises. It is tenable to believe that dalit community suffers from patriarchal regulations as savarna community. As we know, Indian social structure is founded on graded inequality ensuring hierarchical value to its members based on caste firstly and then gender. It is embedded in the brahmanical system that each is oppressed by another upper to her - a brahmin woman by a brahmin man; a kshatriya man by both, a brahmin woman and a brahmin man; a kshatriya woman by three above her, a kshatriya man, a brahmin woman and a brahmin man; and so on. Even if the claim about dalit men's desire to tease savarna women is empirically established, the source of their patriarchal behaviour would only be brahminism, and not something originating from the dalit community itself. This would plausibly be termed as 'dalit manifestations of brahmanical patriarchy.' Similarly, women are also influenced by patriarchal norms. But how fruitful is it to name their patriarchal behaviour as ' women patiarchy'?!

Nevertheless, given historical assessment of patriarchy in the Indian subcontinent, that 'provisions were made for upper caste men's occasional or more regular relationships with lower caste women, the reverse was not even envisaged by the caste structure' (Chakravarti, 2013 [2003], p. 83 ). Sexual assault on dalit women is used as 'a common practice for undermining the manhood of the caste' (Rege, 1998, p. WS 43). Therefore, in the brahmanical social structure regulated by caste, dalit women are regarded as 'easy prey' for exploitation at the hands of savarna men, and never otherwise. This gets explicit in the next instance.

\section{Fallacy of Faulty Analogy}

The claim about existence of brahmanical and dalit patriarchies comes from a superficial understanding of the nature of brahmanical patriarchy. This conjunction presumes a distinction between the two, while misunderstanding the peculiarity of Indian social system. As argued earlier, dalit patriarchy has been misconceived referring to the patriarchal dominance within dalit community, but brahmanical patriarchy is never meant to signal the patriarchal practices and norms followed within the brahmin caste. Rather, it refers to the brahmanical form of patriarchy operating in India; that is, in order to maintain the numerical balance between the sexes of the society, inhumane rituals like the banned sati pratha (i.e., a religious ritual according to which a widow immolated herself in the funeral pyre of her husband), enforced widowhood, and child-marriage were perpetuated by the brahmins. Controlling women's sexuality is still a means to sustain caste system, and therefore, Ambedkar's analysis of patriarchy as the twin-sister of brahmanism is ever-relevant (Ambedkar, 2003 [1979], Vol. 1, p. 14 ). Brahmanical patriarchy is not patriarchy of, or by, the brahmins.

Brahmanical patriarchy includes in its very conceptualisation that all individuals are allotted a particular position of privilege and deprivation, and the resultant violence and discrimination to the lower caste groups. This form of patriarchy ensures slavery and exploitation of the lowest in the prescribed caste-strata, and not peculiar origination from within those regarded lowest. Rethinking through caste and gender 
only establishes that dalit women face caste-based discrimination in the vertical structure of society and gender-based discrimination at the horizontal structure of society. The ambiguous conception of dalit patriarchy hence suffers from logical, empirical and theoretical shortcomings.

Thus, mistaking brahmanical patriarchy as brahmin patriarchy has led to coin dalit patriarchy. To persist towards a better society with justice, freedom, and equality, we need to keep our eyes fixed upon dismantling brahmanical patriarchy. Brahmanical patriarchy operates in a way that caste plays a determining role in 'the collective and public threat of rape, sexual assault, and physical violence at the workplace and in public' (Rege, 1998, p. WS43). Dalit women, being at the bottom of brahmanical hierarchy, suffer the most. Conceptualising dalit or intra-caste patriarchy is indicative of a certain irresponsibility of scholars who enjoy caste-class privilege and disregard dalit women's issues as not 'their' problem. What is at play is the vulnerability at the unique juncture of gender, class, and, majorly, caste.

The above four fallacies evidence an unfortunate disturbance created by the mainstream and savarna feminists of India. Due to misdirection of the above kind, what is at stake is the striving goal for a harmonious and humane society. Refusal of mainstream and savarna feminists to consider dalit women's issues as integral to feminism exhibits their lack of commitment for real gender justice. Thus, it is high time to rethink feminism in Indian context.

\section{Rethinking Indian Feminism}

We witness the failure of mainstream feminist rendition of patriarchy in Indian context, where they attempt to pluralise patriarchy, but, ironically, follow a single axis approach in the feminist enterprise. Since woman as a category does not stand alien to its socio-political and cultural situations, we must locate it in its complex relation to factual grounds. This is precisely why we must rethink feminism. Indian feminist discourse - dominated by savarna women, whose suppression of the caste question and overlooking of the non-brahmanic Ambedkarite feminist standpointsdemonstrates that only a dalit feminist thought can help us resolve patriarchal slavery of women in India. A dalit feminist standpoint will be discussed in the second part of this section. Let us see why is this necessary.

\section{Caste as a Catalyst in Patriarchal Dominance}

In reference to the 2006 Khairlanji massacre of a dalit family, where women were paraded naked before being murdered, Rege argues that due to lack of adequate focus on the caste-gender nexus, violence against dalit women tends to be marked in 'eitheror' restriction-as 'either caste atrocity or sexual atrocity' (2003, p. 20). For the brahmanical nature of violence and exploitation of women, the issue of gender cannot be dealt in isolation, but only with an interaction with our social reality.

Indian society is predominantly structured around caste, which is evident through the example of honour killing. ${ }^{2}$ Two reasons are commonly responsible for a couple's murder by their parents, guardians, or local authorities: one, they dare to pursue marriage unconventionally by their own; or secondly, more venturing, they chose their life-partner outside of their own caste. Defying caste norms are considered as an invitation to murder, rape, and such life-threatening risks in a casteist society like India's. 
Because endogamy is the foundation for regulating and organising women's sexuality, Rege draws upon Ambedkar's theoretical vantage to argue that, 'caste determines the division of labour, sexual division of labour, and division of sexual labour' (Rege, 1995). We cannot separate caste from patriarchy. In order to dismantle patriarchy, we must understand that,

Brahmanisation has been a two way process of acculturation and assimilation and through history there has been a brahmanical refusal to universalise a single patriarchal mode. Thus the existence of multiple patriarchies is a result of both brahmanical conspiracy and of the relation of the caste group to the means for production.

(Rege, 1998, p. WS44)

Rege's analysis renders it clear that brahmanical patriarchy functions in a way that different caste people experience it differently because of the existing graded pattern of inequality. No politics committed to a caste-based society can overlook sexual politics. Contextually, a single axis framework bears no fruits; there is need to rethink both, dalit as well as feminist discourses.

Recollecting cases like Bhanwari Devi, Chanduru, Babri Masjid, and others from recent history of India, Rege advocates that in the absence of dalit critiques of classbased hetro-patriarchies, the political edge of sexual politics is lost (2000, p. 493). Mainstream feminists' denial of the dalit question compels us to think critically and carefully. ${ }^{3}$ Singular approaches on gender or caste are determined to fail due to their limited engagement with the crosshatched embedding of caste with patriarchy.

\section{A Dalit Feminist Resolve}

Any idea of gender justice bears no meaning if it does not entail justice for all; therefore, pioneers of black feminism Kimberle Crenshaw, Patricia Hill Collins, and others have democratised first-world feminism by adding 'difference' at its centre through intersectionality (Crenshaw, 1989; Colloins, 1989). Originally, the difference has been conceived as a unique kind of discriminatory aspect which black women face due to their race-gender-class deprivations. Mainstream feminists of India accept this crucial concept of 'difference' and intersectionality, for their difference located in third-world and on race, but reject the same for internal differences within the subcontinent (Menon, 2015). Rege offers a critique of this difference from a dalit feminist standpoint position, arguing that it is incomplete without an addition of difference from the aspect of caste (Rege, 1998, p. WS39-WS46). Thus, it is evident that democratising Indian feminism demands theorising from a dalit perspective.

The difference, thus formulated, is the unique discriminatory aspect which dalit women face at the intersection of their caste-class-gender deprivations, which as the author calls 'dalit difference.' Placing dalit difference at the core of feminist thought helps us consummate feminist philosophy, as it does not contradict with the rights and interests of other, privileged people. Dalit feminism is not the feminism of the dalits, or for the dalits; it is simply a standpoint which regards the caste question at its heart, to address the brahmanical nature of patriarchy peculiar to India. There is abundant scholarship to help us develop a dalit feminist thought (Guru, 1995; Rege, 1998, 2000, 2013 [2006], 2013; Ambedkar, 2003; Rajan, 1999; Aloysius, Mangubhai and Lee, 2006; Jogdand, 2013; Patil, 2013; Rege et al, 2013; Pawar and Moon, 2014; 
Gopal, 2015; John, 2015; Mahadevan, 2015; Paik, 2016). Importantly, it is required to be cognizant of, and overcome, some challenges.

\section{Challenges for a Theory of Gender}

Established critiques of Indian feminism call forth our attention to the questions of authenticity and representation. There is an anxious churning to interview, study, and translate dalit women's life-stories to produce literature to the credits of savarna women as representatives (Rege, 2013 [2006], pp.11-121). Mainstream Indian feminists have been exploiting dalit women's vulnerability to add to their own privileges, and such risks are indispensable in developing a theory of gender.

Julie Stephens argues that '[i]f anyone is actually 'speaking out', it is the interviewer, yet the feminist discourse repeatedly insists that it 'does not speak for' them (Stephens, 1994, p. 97). Rege mentions two models for the 'inclusion' of dalit women in any discipline's curricula - (i) 'feminist-as-tourist' suggesting 'add dalit women and stir'; and, (ii) 'feminist-as-explorer' to 'add dalit women as separate and equal' (Mohanty, 2003, 244). That is, the-tourist model performs a 'cognizant saviour feminist' enlightening the 'helpless dalit women'; the -explorer model pretends to treat them 'equally' while justifying their separation on cultural differences. This power-play is commonly observed in contemporary feminist writings in India, which we must discourage.

Nevertheless, Indian feminist literature exhibits constant attempts of denying agency of dalit women and disregarding dalit feminist scholarship — by calling them 'native narrators' who are objects of study and not subjects of feminist agenda; by alienating them with an 'us-them' dichotomy; by reducing dalit feminist discourse to 'works of poetry, short stories, and other forms of writing' as opposed to theoretical, intellectual, or academic scholarship; by separating dalit feminist activism with phrases viz. 'feminism and other forms of politics'; feminists and other subaltern forces; and so on (Tharu, 2014, p. 155; Chakravarti, 2012-2013, pp. 137, 143; Tharu and Niranjana, 1996, pp. 232-260, pp. 232). Such forms of othering and 'brahmanical superiority complex' are strong challenges while conceiving a feminist theory.

\section{Conclusion}

As we have discussed in the three sections, mainstream Indian feminism evidences a lack of commitment towards the gender justice for the most marginalised. We need to encourage the most marginalised to take up the lead for an authentic theory of gender. What is required is an active participation of dalit women unravelling the theoryexperience hierarchy, and simultaneously, an active refraining from the differences of caste, class, region, language, culture, etc. barriers. The subject and the object of feminist research need to overlap. Dalit women's empowerment is required to enable theoretical articulation of the lived-experiences; and improvement of education and research is necessary for its smooth access to dalit women.

Nonetheless, an honest and egalitarian standpoint taken up by a non-dalit or nonwoman is encouraged. The participation of the privileged in an emancipatory agenda plays a significant role, provided their sincere commitment to a goal in the given context. Dalit feminist theorisation by a non-dalit woman Sharmila Rege and by a dalit man Gopal Guru offers a possibility of collective progress towards an egalitarian society; while the non-committed articulation and brahmanical othering of dalit 
feminism by many savarna and privileged writers flags to a greater risk in this journey. Aspiring emancipation of all, an indepth scrutiny is a necessity.

Feminist endeavours which strive to protect and encourage the rights of the most deprived are substantial. It is high time that the approaches which are misled by untenable concepts like dalit patriarchy should return to its real goals. We cannot hope to create a gender-just theory with the biases and irresponsibility which most of the privileged 'representatives' of feminism manifest. A dalit feminist standpoint, essentially the dalit difference - primarily dalit women's experience - is a must to develop an emancipatory feminist theory.

\section{References}

Aloysius, S. J., Mangubhai, Jayashree P., and Lee, Joel G. (Eds.) (2006). Dalit women speak out: violence against dalit women in India. New Delhi: Zubaan.

Ambedkar, B. R. (2003). Babasaheb Ambedkar's writings and speeches (collec. and ed. Vasant Moon).

Arya, Sunaina and Aakash Singh Rathore. (2019). Dalit Feminist Theory: A Reader. London: Routledge.

Arya, Sunaina. (2017). An enquiry into Ambedkar as a feminist philosopher. M. Phil. dissertation, submitted to Centre for Philosophy, New Delhi: Jawaharlal Nehru University, July 26.

Chakravarti, Uma. (1993). Conceptualising Brahmanical patriarchy in early India: gender, caste, class and state. Economic and Political Weekly, 28 (14), April 3, 579-585.

Chakravarti, Uma. (2012-13). In Her Own Write: Writing from a Dalit Feminist Standpoint. India International Centre Quarterly, 39 (3/4), Winter-Spring, 134-145.

Chakravarti, Uma. (2013). Gendering caste: through a feminist lens, Calcutta: Stree. First published in 2003.

Collins, Patricia Hill. (1989). The social construction of black feminist thought. Signs: Journal of Women in Culture and Society, Vol. 14, No. 4, Common Grounds and Crossroads: Race, Ethnicity, and Class in Women's Lives, Summer, University of Chicago Press, 745-773.

Crenshaw, Kimberle. (1989). Demarginalizing the intersection of race and sex: a black feminist critique of antidiscrimination doctrine, feminist theory and antiracist politics. University of Chicago Legal Forum, I(8), pp. 140-167.

Dhanaraj, Christina Thomas. (2019). Book Review of Yashica Dutt's Coming Out as Dalit. Scroll.in, March 23. Accessed from https://scroll.in/article/917384/this-poignant-memoirabout-coming-out-as-dalit-provokes-the-question-whom-do-we-write-for, on April 11, 2019.

Dutt, Yashica. (2019). Coming Out as Dalit: A Memoir. New Delhi: Aleph Book Company.

Geetha, V. (2009). Patriarchy, Kolkata: Stree.

Gogu, Shyamala. (2012). Father May Be an Elephant and Mother Only a Small Basket, But..., translated from Telugu, Hyderabad: Navayana.

Gokhale, Pradeep. (2008). The Philosophy of Dr. B. R. Ambedkar. Pune: SugavaPrakashan on behalf of Indian Philosophical Quarterly Publication.

Gopal, Meena. (2015). Struggles around gender: some clarifications. Economical and Political Weekly, 50 (33), 76-77.

Guru, Gopal. (1995). Dalit women talk differently. Economical and Political Weekly, 30 (41/42), Oct. 14-21, 2548-2550.

Guru, Gopal and Sarukkai, Sundar. (2012). The cracked mirror: an Indian debate on experience and theory. New Delhi: Oxford University Press. 
Illaiah, Kancha. (1996). Why i am not a Hindu: a sudra critique of Hindutva philosophy, culture and political economy, Calcutta: Samya.

Jogdand, P. G. (2013). Dalit Women: Issues and Perspectives, New Delhi: Gyan Publishing House.

John, Mary E. (2015). Intersectionality: rejection or critical dialogue. Economical and Political Weekly, 50(33), 72-76.

Kamble, Swati. (2018, May 8). When love is brutal: personal narrative of surviving domestic abuse', Savari, Dalit Web. Accessed from https://www.dalitweb.org/?p=3222 on July 18, 2019.

Kannabiran, Vasanth and Kannabiran, Kalpana. (1991). Caste and gender: understanding dynamics of power and violence. Economic and Political Weekly, 26(37), 2130-2134.

Lucinda, Ramberg. (2018). Casting Religion and Sexing Gender in South India. In Anupama Rao (Ed.), Gender, caste and the imagination of equality (pp. 37-57), New Delhi: Women Unlimited.

Mahadevan, Kanchana. (2015). Experience and representation: beyond hierarchy. Labrys, etudes feminists/ estudosfeministas, no. 27, January-June, pp. 1-20, http: www.labrys.net.br.

Menon, Nivedita. (2015). Is feminism about 'women'? a critical view on intersectionality from India. Economical and Political Weekly, 50(17), April 25, pp. 37-44.

Moon, Vasant. (2001). Growing up untouchabale in India: a dalit autobiography (trans. Gail Omvedt, intro. Eleanor Zelliot), first published in Marathi as Vasti in 1995, New Delhi: Vistaar Publications.

Paik, Shailaja. (2016). Forging a new dalit womanhood in colonial India: discourse on modernity, rights, education, and emancipation. Journal of Women's History, Johns Hopkins University Press, 28(4), Winter, 14-40.

Patil, Smita, M. (2013). Revitalising dalit feminism: towards reflexive anti-caste agency of Mang and Mahar women in Maharashtra. review of women's studies, Economic and Political Weekly, 48(18), May 4, 37-43.

Pawar, Urmila and Moon, Meenakshi. (2014). We also made history: women in the Ambedkarite movement (trans. and intro. Wandana Sonalkar), New Delhi: Zubaan Academic.

Rajan, Rajeswari, Sunder. (Ed.) (1999). Signposts: gender issues in post-independence India. New Delhi: Kali for Women.

Rani, Challapalli, Swaroopa. (1998). Dalit women's writing in Telugu: review of women's studies, Economic and Political Weekly, 33 (17), April 25, also available on https://www. epw.in/journal/1998/17/review-womens-studies-review-issues-specials/dalit-women-swriting-telugu.html.

Rege, Sharmila. (1998). Dalit women talk differently: a critique of 'difference' and 'towards a dalit feminist standpoint position', Economical and Political Weekly, 33(4), Oct. 31 - Nov. 6, WS39-WS46.

Rege, Sharmila. (2000). Real feminism and Dalit women. Economical and Political Weekly, 35 (6), February 5, 492-495

Rege, Sharmila.(Ed.) (2013). Writing caste/writing gender: narrating Dalit women's testimonies. New Delhi: Zubaan. First published by Kali for Women in 2006.

Rege, Sharmila. (2013). Caste and gender: the violence against women in India. In P. G. Jogdand (Ed.), Dalit women: issues and perspectives (pp. 18-36), New Delhi: Gyan Publishing House.

Rege, Sharmila. (2013). Against the madness of Manu: B. R. Ambedkar's writings on brahmanical patriarchy. New Delhi: Navayana. 
Rege, Sharmila, Devika, J., Kannabiran, Kalpana, John, Mary E., Swaminathan, Padmini and Sen, Samita. (2013). Intersections of gender and caste. Economical and Political Weekly, 48(18), May 4, 35-36.

Sangari, Kumkum. (1995). Politics of diversity: religious communities and multiple patriarchies. Economic and Political Weekly, 30 (51), 3287-3310.

Stephen, Cynthia. (2011). A name of our own. Journal of Dharma, 36(4), October-December, 419-434.

Stephens, Julie. (1994). Feminist fictions: a critique of the category 'non-western woman' in feminist writings on India. In Ranjit Guha (Ed.), Subaltern studies VI: writings on South Asian history and society (pp. 92-125), Delhi: Oxford University Press.

Tharu, Susie and Niranjana, Tejaswini. (1996). Problems for a contemporary theory of gender. In Shahid Amin and Dipesh Chakrabarty (Eds.), Subaltern studies IX: writings on South Asian history and society (pp. 232-260), New Delhi: Oxford University Press.

Tharu, Susie. (2014). The dalit woman question. Indi@logs, 1, 152-159.

Tharu, Susie. Rege, Sharmila. Response to Julie Stephens. (1994). In Ranjit Guha (Ed.), Subaltern studies VI: writings on South Asian history and society (pp. 126-131), Delhi: Oxford University Press.

Tilak, Rajni. (2018). Need to redefine dalit movement. Indian Cultural Forum, April 2. Accessed from http://indianculturalforum.in/2018/04/02/need-to-redefine-dalit-movementrajni-tilak/ and https://roundtableindia.co.in/index.php?option=com_content\&view=articl e\&id=6155:need-to-redefine-dalit-movement-rajni-tilak\&catid=119:feature \&Itemid=132 on July 17, 2019.

\section{Endnotes}

1. Hierarchical terms like 'upper' or 'lower' is used in reference to a caste-stratified society, and not encouraged by the author

2. 'Honour killing' is a term used for murders when people believe that they are protecting their 'honour' by murdering those defying social norms preached by brahmanical system.

3. See Stephen, 2011. 